\title{
PUSAT INFORMASI DI RUANG PUBLIK TERPADU RAMAH ANAK (RPTRA) GUNA MENINGKATKAN KECAKAPAN HIDUP (LIFE SKILLS) REMAJA URBAN
}

\author{
Supriyanto $^{1}$, Veronica Anastasia Melany Kaihatu² dan Teguh Prasetio ${ }^{3}$ \\ 1,* Program Studi Psikologi, Universitas Pembangunan Jaya (UPJ) \\ ${ }^{1}$ Program Studi Psikologi, Universitas Pembangunan Jaya (UPJ) \\ ${ }^{2}$ Program Studi Manajemen, Universitas Pembangunan Jaya (UPJ) \\ *Email: supriyanto@upj.ac.id
}

\begin{abstract}
ABSTRAK
Ruang Publik Terpadu Ramah Anak atau yang dikenal dengan RPTRA telah dibangun dan diimplementasikan oleh Pemerintah Provinsi Daerah Khusus Ibukota (DKI) Jakarta sejak tahun 2015. Universitas Pembangunan Jaya (UPJ) melalui mekanisme Penelitian dan Pengabdian Masyarakat turut berkontribusi dalam merencanakan, mengembangkan dan mendukung program RPTRA. Artikel ini menggambarkan kegiatan Pengabdian Masyarakat yang dilaksanakan oleh Program Studi Psikologi dan Manajemen UPJ di RPTRA Anggrek, Kelurahan Bintaro, Jakarta Selatan. Tujuan Pengabdian Masyarakat ini yaitu untuk memperkuat fungsi RPTRA Anggrek sebagai pusat informasi yang menyediakan sumber referensi dan pengetahuan bagi masyarakat. Secara lebih khusus, kegiatan pengabdian selama enam bulan ini berbentuk pemberian pengetahuan dan penyebaran informasi mengenai kecakapan hidup (life skills) baik personal skills, social skills maupun academic skills kepada para remaja dan orang tua yang memiliki anak remaja yang berdomisili di sekitar RPTRA. Output dari kegiatan Pengabdian Masyarakat ini antara lain berupa papan informasi, poster, artikel populer di media sosial dan artikel ilmiah untuk publikasi di jurnal/proceeding.
\end{abstract}

Kata Kunci: Ruang Publik Terpadu Ramah Anak (RPTRA), kecakapan hidup, pengabdian masyarakat

\section{ABSTRACT}

Ruang Publik Terpadu Ramah Anak (RPTRA) has been built and implemented by the Provincial Government of Jakarta since 2015. Universitas Pembangunan Jaya (UPJ) through Research and Community Service mechanism has a significant role in planning, developing and supporting the RPTRA program. This article describes community service activities conducted by the Department of Psychology and Management UPJ at RPTRA Anggrek, Bintaro, South Jakarta. The purpose of community service is to strengthen the function of RPTRA Anggrek as an information center that provides a source of reference and knowledge for the community members. More specifically, these six months of community service activities provide knowledge and information on life skills (personal skills, social skills and academic skills) to teenagers and their parents who live around RPTRA Anggrek area. The output of the activity includes information board, posters, popular articles for social media and scientific article published in journal/proceeding.

Keyword: Ruang Publik Terpadu Ramah Anak (RPTRA), life skills, community service 


\section{PENDAHULUAN}

RPTRA Anggrek Bintaro yang dibangun atas kerjasama antara Pemerintah Provinsi DKI Jakarta dan pihak swasta (PT Metropolitan Kentjana, Tbk.) diresmikan oleh Gubernur DKI Jakarta Basuki Tjahaja Purnama pada tanggal 20 Januari 2016 (Antara, 2016). RPTRA Anggrek Bintaro memiliki total luas area 2.376 meter persegi dan dilengkapi fasilitas aula, lapangan futsal, taman bermain, kolam ikan, area berkebun untuk warga, perpustakaan, ruang pelayanan kesehatan, ruang laktasi dan ruang serba guna. RPTRA Anggrek Bintaro beralamat di Villa Anggrek Bintaro Jl. Garuda Bawah RT 08/RW 12, Bintaro, Pesanggarahan Jakarta Selatan, DKI Jakarta 12330.

RPTRA Anggrek Bintaro ini merupakan satu dari total 306 RPTRA yang dibangun Pemprov DKI sampai tahun 2017 (Detik, 2015).Tujuan Pemprov DKI Jakarta membangun RPTRA adalah sebagai community center. Cara ini dilakukan oleh Pemprov DKI Jakarta dengan membeli lahan kosong tak terpakai di wilayah pemukiman warga miskin. Melalui kemitraan dengan sederetan perusahaan, Pemprov DKI Jakarta mengembangkan fasilitas RPTRA berdasarkan 31 indikator kota layak anak yang ditetapkan Kementerian Pemberdayaan Perempuan dan Anak (KemenPPA). Proses pembangunan dan perawatan RPTRA melibatkan warga karena RPTRA memosisikan warga sebagai pemilik dan pengelola taman. Melalui RPTRA, calon penerus bangsa diharapkan mendapatkan kualitas hidup yang lebih baik dan sehat sehingga tercipta manusia-manusia yang sehat, bahagia dan pintar (Kompasiana, 2016).

Universitas Pembangunan Jaya (UPJ) secara khusus terlibat dalam pembangunan RPTRA Anggrek Bintaro yang didirikan dengan dana Corporate Social Responsibility (CSR) PT Metropolitan Ketjana, Tbk. (Universitas Pembangunan Jaya, 2016a). Peran serta UPJ di RPTRA Anggrek diawali mulai dari kegiatan pemetaan sosial (social mapping) pada tahap awal, monitoring pembangunan secara fisik sampai terlibat dalam kegiatan-kegiatan penelitian, pendidikan dan pengabdian masyarakat. Pada tanggal 3-4 dan 10-11 Desember 2016, sekelompok mahasiswa Prodi Psikologi UPJ berinisiatif untuk memberikan pelatihan keterampilan sosial (social skills) pada anak-anak usia sekolah yang tinggal di sekitar RPTRA Anggrek dan sering memanfaatkan fasilitas RPTRA Anggrek. Pada pelatihan social skills tersebut secara khusus anak-anak belajar mengenai keterampilan berkomunikasi, bekerja sama, empati dan perilaku pro-sosial.

Kerjasama selanjutnya adalah kegiatan penelitian antara RPTRA Anggrek dengan Program Studi Psikologi dan Manajemen dengan tajuk Analisis Kebutuhan Keluarga Urban dalam Memanfaatkan Lapangan Bermain Guna Optimalisasi Pengasuhan Anak: Studi Kasus RPTRA Anggrek Bintaro. Penelitian yang mendapatkan dukungan Pusat Penelitian dan Pengabdian Masyarakat (P2M) UPJ melalui Hibah Penelitian Fundamental ini menjawab pertanyaan tentang gambaran keluarga urban yang berdomisili di wilayah RPTRA Anggrek Bintaro dalam memanfaatkan aset kota untuk mengoptimalkan pengasuhan anak usia pra sekolah (3-5 tahun) dan usia sekolah (6-12 tahun). Penelitian yang dilakukan antara Januari 2016-Januari 2017 ini bertumpu pada kenyataan bahwa keluarga yang tinggal di lingkungan kota (urban family) menghadapi tantangan tersendiri sebagai konsekuensi dari lingkungan sosial tempat mereka tinggal. Oleh karena itu, penting untuk fokus pada sumber daya (resources), kekuatan (strengths) maupun aset (assets) serta peluang (opportunities) yang terdapat di kota, strategi untuk memaksimalkan beraneka sumber daya yang ada di kota serta memahami bagaimana sumber daya tersebut dapat diterjemahkan menjadi peningkatan kesejahteraan bagi mereka-mereka yang tinggal di kota, termasuk di dalamnya keluarga urban. Untuk bisa mencapai hal-hal tersebut di atas, terdapat banyak potensi kota yang dapat dimanfaatkan oleh orang tua untuk mengoptimalkan pengasuhan anak. 
Hasil penelitian menunjukkan bahwa responden penelitian (orang tua) yang berdomisili di wilayah RT 06, RT 07, RT 08, RW 12 kelurahan Bintaro, Jakarta Selatan cukup aktif dalam mengakses, memanfaatkan dan menggunakan fasilitas yang tersedia dan berpartisipasi dalam kegiatan-kegiatan yang diselenggarakan di RPTRA Anggrek, Bintaro. Terdapat keselarasan antara kondisi warga, kebutuhan-kebutuhan warga dan layanan yang disediakan oleh pengelola RPTRA Anggrek. Pemanfaatan RPTRA Anggrek oleh responden sangat beragam mulai untuk kegiatan rekreasional, olahraga, hiburan, sosialisasi/interaksi antar warga, edukasi, pertunjukan kesenian, pelatihan vokasional, pendidikan anak, pengasuhan anak, sampai untuk mendapatkan layanan kesehatan. Beragamnya aktivitas dan layanan RPTRA Anggrek ini tidak terlepas dari kinerja pengelola RPTRA yang aktif menyelenggarakan kegiatan dan mengundang warga untuk turut berpartisipasi (Supriyanto, Soerjoatmodjo \& Prasetio, 2017).

Penelitian juga merekomendasikan untuk memaksimalkan potensi, fungsi dan kebermanfaatan RPTRA Anggrek bagi masyarakat sekitar, antara lain: a) Menyediakan sumber informasi dan referensi kepada pengelola RPTRA Anggrek dalam berbagai bentuk seperti buku, modul, buku panduan, booklet, poster, dan lain sebagainya. Penyediaan sumber informasi dan referensi ini diharapkan dapat menjembatani keterbatasan-keterbatasan yang dimiliki oleh pengelola RPTRA Anggrek sehingga mereka dapat memperoleh tambahan pengetahuan dari sumber yang relevan dan akurat; b) Menyediakan papan informasi di RPTRA Aggrek beserta dengan materi-materi psikoedukasi yang dikembangkan sesuai dengan kebutuhan warga dan pengelola RPTRA. Diharapkan pengetahuan dan pemahaman warga dan pengelola RPTRA dapat meningkat setelah mereka mengakses papan informasi ini (Supriyanto, Soerjoatmodjo \& Prasetio, 2017).

Sementara itu, terhitung sejak 30 Juni 2016, Pemerintah Provinsi DKI Jakarta dan Universitas Pembangunan Jaya menyusun Perjanjian Kerjasama tentang Pembinaan dan Pendampingan Program Kependudukan Keluarga Berencana dan Pembangunan Keluarga (PKS No 008/PER-REK/UPJ/06.16). Program Kependudukan Keluarga Berencana dan Pembangunan Keluarga (KKBPK) merupakan program yang bertujuan mewujudkan pembangunan berwawasan kependudukan dan mewujudkan keluarga kecil bahagia sejahtera. Dalam Perjanjian Kerjasama ini, khususnya Pasal 5 ayat 2, UPJ berkewajiban antara lain menyediakan bahan materi untuk sosialisasi untuk remaja maupun keluarga yang memiliki anak usia remaja tentang keterampilan hidup (life skills) (Universitas Pembangunan Jaya (2016d).

Berdasarkan hasil temuan dan rekomendasi penelitian di atas, serta dalam rangka mewujudkan program Kependudukan Keluarga Berencana dan Pembangunan Keluarga, maka tim dari Program Studi Psikologi dan Manajemen mengusulkan dilaksanakannya sebuah kegiatan Pengabdian Masyarakat di RPTRA Anggrek Bintaro. Tujuan dari kegiatan Pengabdian Masyarakat ini yaitu untuk memberikan pengetahuan dan pemahaman kepada remaja dan warga di sekitar RPTRA Anggrek Bintaro (termasuk staf pengelola RPTRA) mengenai kemampuan/kecakapan hidup (life skills) yang relevan dengan kehidupan remaja sehari-hari.

\section{TINJAUAN PUSTAKA}

Life skills adalah kecakapan seseorang untuk berani menghadapi problema hidup dan kehidupan secara wajar tanpa merasa tertekan, kemudian secara proaktif dan kreatif mencari serta menemukan solusi sehingga akhirnya mampu mengatasinya (Supriatna, 2005). Life skills dibutuhkan oleh seseorang untuk menjaga kelangsungan hidup dan pengembangan dirinya. Pada dasarnya life skills dapat dibedakan menjadi dua, yaitu: 1) kecakapan hidup umum (generic life skills) dan 2) kecakapan hidup spesifik (specific life skills). Kecakapan hidup umum adalah kecakapan yang harus dimiliki oleh setiap manusia yang terdiri atas 
kecakapan personal (personal skills) dan kecakapan sosial (social skills). Kecakapan personal mencakup kesadaran diri atau memahami diri sendiri (self-awareness), serta kecakapan berpikir (thinking skills). Kesadaran diri merupakan penghayatan diri sebagai mahluk Tuhan Yang Maha Esa, anggota masyarakat dan warga Negara, serta menyadari dan mensyukuri kelebihan dan kekurangan yang dimiliki sekaligus menjadikannya sebagai modal dalam meningkatkan dirinya sebagai individu yang bermanfaat bagi diri sendiri dan lingkungannya. Sementara kecakapan berpikir mencakup kecakapan (1) mengali dan menemukan informasi, (2) mengolah informasi dan mengambil keputusan, dan (3) memecahkan masalah secara kreatif.

Lebih jauh lagi, Supriatna (2005) menjelaskan bahwa kecakapan sosialisasi atau kecakapan antar pribadi (interpersonal skills) meliputi kecakapan berkomunikasi dengan empati dan kecakapan bekerjasama (collaboration skills). Pada kecakapan komunikasi seperti empati, sikap penuh pengertian dan seni berkomunikasi dua arah perlu ditekankan, karena berkomunikasi bukan sekedar menyampaikan pesan, tetapi isi dan sampainya pesan disertai dengan kesan baik yang akan menumbuhkan hubungan harmonis. Kecakapan komunikasi sangat diperlukan karena manusia berinteraksi dengan manusia lain melalui komunikasi, baik secara lisan, tertulis, tergambar maupun melalui kesan. Kecakapan komunikasi terdiri dari dua bagian, yaitu verbal dan non-verbal. Komunikasi verbal meliputi kecakapan mendengarkan berbicara, dan membaca-menulis. Komunikasi non-verbal meliputi pemahaman atas bahasa tubuh, dan tampilan atau peragaan. Dengan demikian, dalam kecakapan komunikasi tercakup kecakapan mendengarkan, berbicara, dan kecakapan menulis pendapat/gagasan. Sementara itu, dalam kecakapan bekerjasama tercakup kecakapan sebagai teman kerja yang menyenangkan dan sebagai pemimpin yang berempati. Sebagai teman yang menyenangkan, seseorang harus mampu membangun iklim yang kondusif dalam bersosialisasi diantaranya menghargai orang lain secara positif, membangun hubungan dengan orang lain dan sikap terbuka. Dalam kepemimpinan tercakup aspek tanggung jawab, sosialisasi, teguh, berani, mampu mempengaruhi dan mengarahkan orang lain.

Kecakapan hidup spesifik (specific life skills) menurut Supriatna (2005) 1 adalah kecakapan yang diperlukan seseorang untuk menghadapi problema bidang khusus seperti pekerjan/kegiatan dan atau keadaan tertentu, yang terdiri atas kecakapan akademik dan vokasional. Kecakapan akademik antara lain seperti kecakapan mengidentifikasi variabel dan menjelaskan hubungannya dengan suatu fenomena tertentu, merumuskan hipotesis terhadap suatu rangkaian kejadian, serta merancang dan melaksanakan penelitian untuk membuktikan suatu gagasan atau keingintahuan. Kecakapan vokasional terkait dengan bidang pekerjaan atau kegiatan tertentu yang terdapat di masyarakat dan lebih memerlukan keterampilan life skills. Dalam kecakapan vokasional tercakup kecakapan vokasional dasar atau pravokasional yang meliputi kecakapan menggunakan alat kerja, alat ukur, memilih bahan, merancang produk; dan kecakapan vokasional penunjang yang meliputi kecenderungan untuk bertindak dan sikap kewirausahaan.

Amirin (2002) menjelaskan bahwa orang yang cakap hidup adalah orang tersebut memiliki pengetahuan (knowledge) dan keterampilan (skills) tertentu untuk bisa hidup layak dalam keadaan apapun. Orang cakap hidup tidak harus menjadi orang yang berharta tetapi bisa mengatur, mengelola hidup dan kehidupannya dengan baik. Kecakapan hidup ini penting untuk dimiliki oleh kelompok usia remaja maupun keluarga yang memiliki anak usia remaja (Departemen Pendidikan Nasional Pusat Pusat Pengembangan Kualitas Jasmani, 2007). Hal ini karena masa remaja merupakan masa transisi dari kanak-kanak menuju dewasa. Di masa yang lekat dengan berbagai tekanan kelompok, proses transisi menjadi dewasa ini membutuhkan persiapan antara lain sadar akan jati dirinya sendiri, mampu memutuskan halhal yang penting dalam hidup, membangun rasa bangga dan kepercayaan diri, belajar 
bekerjasama, menghargai orang lain, belajar mempengaruhi orang lain secara konstruktif, berpikir kritis, berkomunikasi secara asertif, mengatasi stress dan lain sebagainya.

\section{BAHAN DAN METODE PELAKSANAAN}

Kegiatan Pengabdian Masyarakat dilaksanakan dalam kurun waktu enam bulan (April 2017 September 2017) dengan melibatkan tim pelaksana dari Program Studi Psikologi dan Manajemen bekerja sama dengan staf RPTRA Anggrek Bintaro. Tahapan-tahapan kegiatan, prosedur sistematis dalam mengidentifikasi kebutuhan dari mitra dan penerima manfaat serta metode pendekatan yang digunakan dalam kegiatan ini sebagai berikut:

\section{Persiapan dan Perencanaan}

Tim dari Prodi Psikologi dan Manajemen bertemu dengan tim RPTRA Anggrek untuk membuat kesepakatan kerjasama sebagai mitra, merencanakan kegiatan, menentukan peran masing-masing pihak dan output yang hendak dicapai pada akhir kegiatan. Pada tahap ini tim pelaksana dari UPJ juga telah menyusun panduan FGD dan menentukan jądwal keoiatan untuk melaksanakan Focys Group Discussion (FGD) dengan pihak-nihak
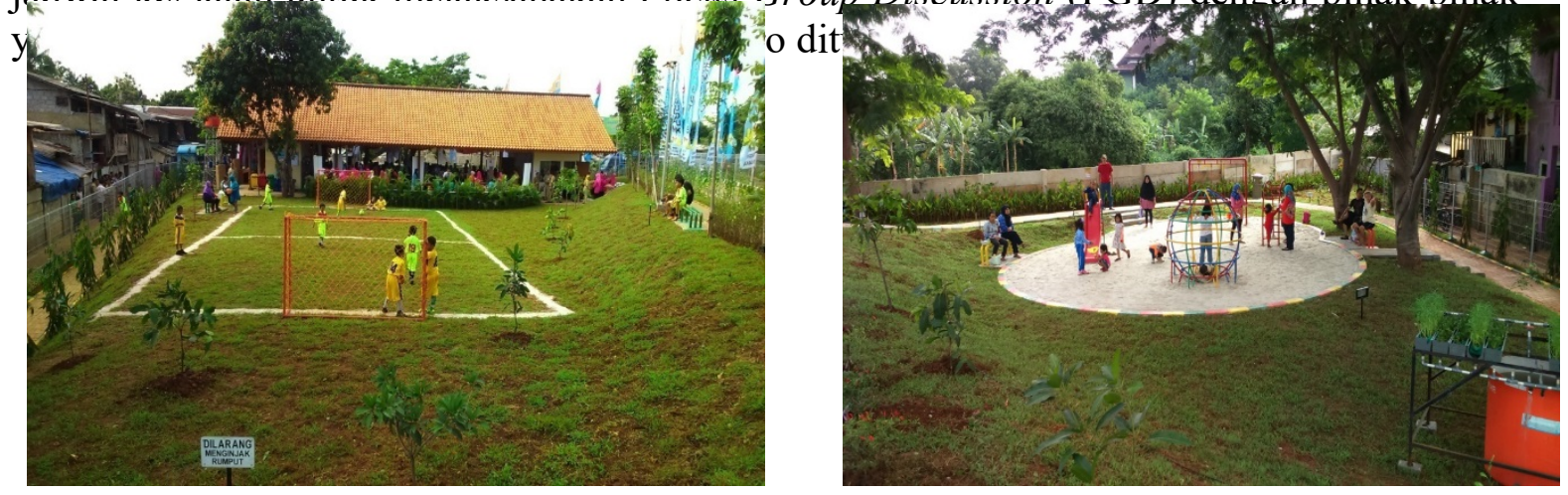

Gambar 1. Lapangan di RPTRA Anggrek Bintaro

Gambar 2. Area Bermain di RPTRA Anggrek Bintaro

\section{Pelaksanaan FGD tahap I}

Focus Group Discussion (FGD) tahap pertama dilaksanakan pada tanggal 17 April 2017 mulai jam 09.00 - 11.30 WIB dengan melibatkan empat staf RPTRA Anggrek, tiga staf dari Prodi Psikologi dan Manajemen serta 2 staf Puskesmas. Tujuan dari FGD tahap I ini adalah untuk mengidentifikasi referensi dan sumber daya yang dibutuhkan oleh RPTRA dan kontribusi tim UPJ dalam melaksanakan kegiatan Pengabdian Masyarakat. Pada FGD ini pihak Puskesmas juga menawarkan untuk berpartisipasi dalam memanfaatkan dan mengisi papan informasi dengan menyediakan informasi-informasi yang berkaitan dengan kesehatan remaja. Berdasarkan hasil diskusi, masalah-masalah yang sering dialami oleh remaja yang tinggal di sekitar RPTRA Anggrek antara lain berkaitan dengan akademis, pilihan karir, relasi sosial, kesehatan reproduksi, pengelolaan keuangan dan tingkah laku berisiko pada kalangan remaja. Pelaksanaan FGD tahap pertama dapat dilihat pada gambar 3. 


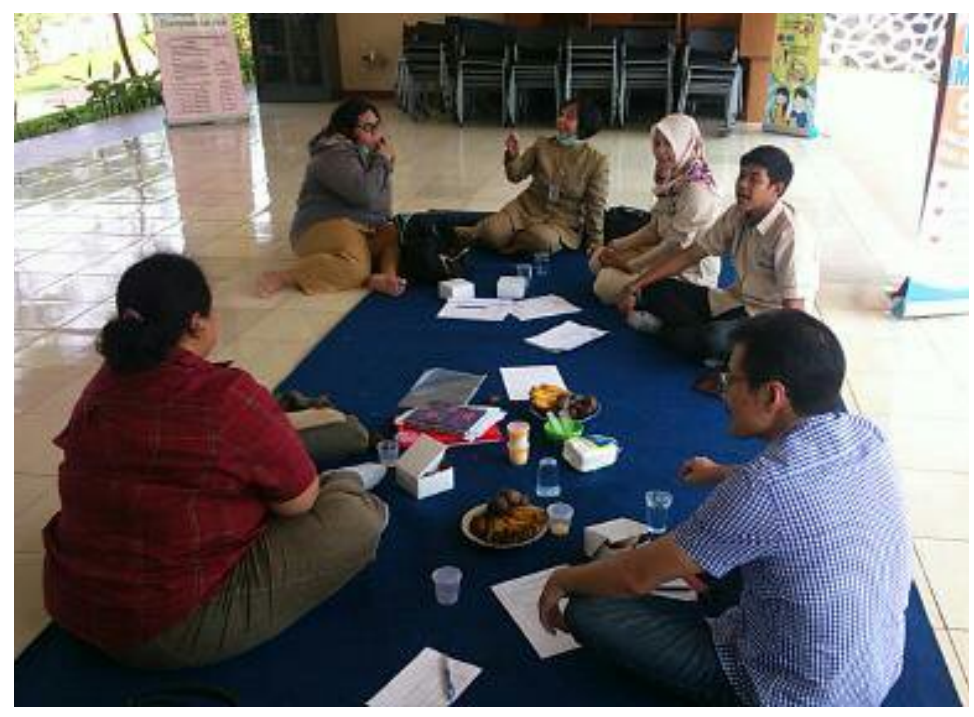

Gambar 3. FGD Tahap I dengan Staf RPTRA \& Puskesmas

\section{Pelaksanaan FGD tahap II}

FGD tahap II dilaksanakan pada tanggal 25 Agustus 2017 dari jam 15.00 - 16.30 WIB. Peserta yang hadir pada kegiatan ini terdiri dari empat orang remaja SMP, empat orang remaja SMA, empat staf RPTRA dan tiga orang tim dari UPJ. Tujuan pelaksanaan FGD tahap II ini yaitu untuk menggali masalah-masalah remaja dari pengalaman dan sudut pandang remaja sendiri, khususnya remaja yang sedang menjalani sekolah di SMP dan SMA. Dari hasil diskusi ditemukan masalah-masalah yang sering mereka hadapi seharihari, antara lain kendala dalam mengelola waktu, kesulitan dalam menentukan sekolah lanjutan setela memiliki gaml dengan orang $t$

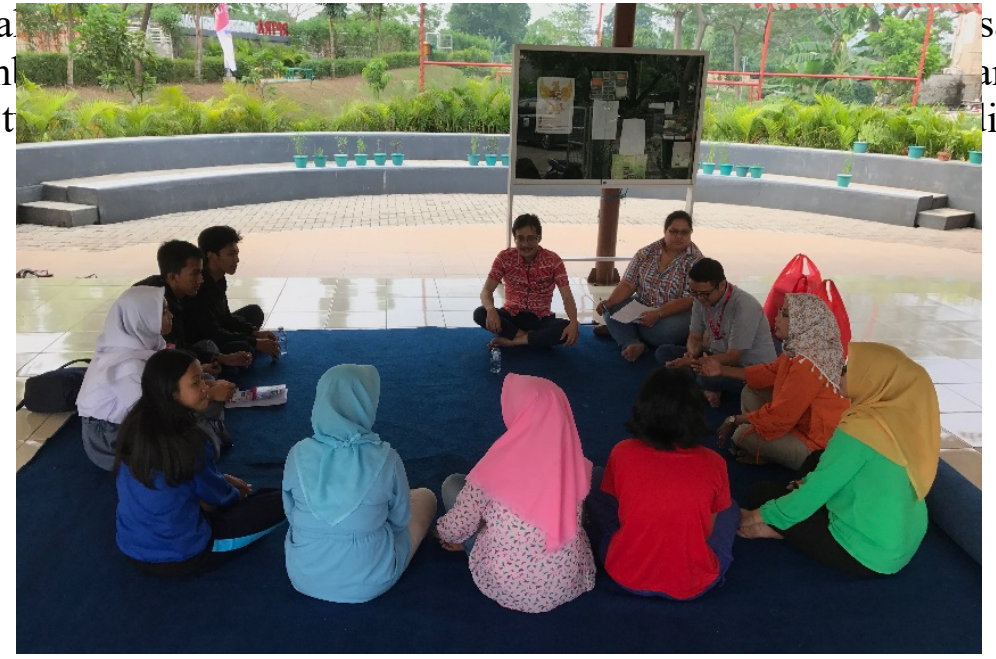
ia sosial.

Gambar 4. FGD Tahap II dengan Remaja 


\section{Menentukan Topik Materi Psikoedukasi}

Tim pelaksana menentukan topik materi-materi psikoedukasi setelah menganalisis hasil FGD tahap I dan II. Sesuai dengan judul proposal Pengabdian Masyarakat, maka topik utama materi psikoedukasi berkaitan dengan life skills untuk remaja dan orang tua yang mempunyai anak remaja di sekitar RPTRA Anggrek.

\section{Menulis Materi Psikoedukasi}

Materi Psikoedukasi yang disusun oleh tim pelaksana disesuaikan dengan kebutuhan dan karakteristik remaja. Meskipun materi tersebut dikembangkan berdasarkan teori-teori dan hasil penelitian di bidang Psikologi, namun bahasa, istilah dan konsepnya akan dimodifikasi sedemikian rupa agar dapat diterima dan dikonsumsi oleh remaja. Untuk tahap awal, penulisan materi psikoedukasi dilakukan oleh dosen, namun pada masa selanjutnya mahasiswa akan dilibatkan dalam penulisan psikoedukasi. Materi psikoedukasi ini nanti akan dipublikasikan dalam website dan dicetak dalam bentuk buku.

\section{Mencetak dan Menyebarkan Poster}

Pembuatan poster baru bisa dilaksanakan setelah materi psikoedukasi selesai ditulis mengingat materi/content yang akan ditampilkan poster diadopsi dari materi psikoedukasi. Poster diberikan ke RPTRA dan dipajang di papan informasi yang ada di RPTRA. Selain dipajang di RPTRA, materi dalam bentuk e-poster juga akan disebarkan ke pihak terkait melalui WA group dan media sosial yang lain.

\section{HASIL DAN PEMBAHASAN}

Hasil yang telah dicapai dalam durasi enam bulan pelaksanaan program Pengabdian Masyarakat di RPTRA Anggrek Bintaro Jakarta Selatan antara lain:

\section{Papan Informasi}

Papan informasi telah diserahkan ke pihak RPTRA dan segera dimanfaatkan oleh mereka untuk menampilkan beberapa informasi yang relevan dengan program RPTRA Anggrek sebelum poster dari tim pelaksana dicetak. Jumlah papan informasi yang diserahkan sebanyak 1 buah. Mengingat papan informasi tersebut dilengkapi dengan kaca pelindung dan roda di bagian bawah, maka papan informasi tersebut dapat dipindah-pindah sesuai dengan kebutuhan, termasuk ditempatkan di luar ruangan. Selain digunakan untuk menginformasikan materi-materi psikoedukasi tentang kecakapan hidup, papan informasi di RPTRA Anggrek juga dapat digunakan untuk menyebarkan informasi dari pihakpihak lain.

\section{Penulisan Artikel Psikoedukasi}

Sesuai dengan perencanaan dan hasil temuan FGD, artikel-artikel psikoedukasi yang disusun oleh tim pelaksana bertema tentang life skills yang dibutuhkan oleh kalangan remaja. Secara lebih spesifik, tema tersebut terbagi dalam empat bidang, yaitu: vocational skills, social skills, personal skills dan academic skills. Tabel 1 menunjukkan enam judul artikel psikoedukasi yang ditulis selama periode pelaksanaan Pengabdian Masyarakat (artikel lengkap terlampir di bagian lampiran).

Tabel 1. Judul dan kategori materi psikoedukasi

\begin{tabular}{|c|l|c|}
\hline No & \multicolumn{1}{|c|}{ Judul } & Kategori \\
\hline 1 & Masalah Akademik Siswa & Academic skills \\
\hline
\end{tabular}




\begin{tabular}{|l|l|l|}
\hline 2 & Memilih Jurusan \& Sekolah & Academic skills \\
\hline 3 & Remaja \& Orang Tua: Mari Berkomunikasi & Social skills \\
\hline 4 & Menjadi Aktif Menuju Sukses & Personal skills \\
\hline 5 & Merajut Karir Sejak Dini & Vocational skills \\
\hline 6 & Cara Mudah \& Ramah Bermedia Sosial & Social skills \\
\hline
\end{tabular}

Berikut penjelasan lebih terperinci mengenai judul artikel psikoedukasi:

\section{a. Masalah Akademik Siswa}

Artikel ini membahas masalah-masalah akademik yang sering dihadapi oleh para remaja, yaitu: motivasi belajar yang rendah, menunda tugas sekolah (prokrastinasi), sikap dan kebiasaan belajar yang tidak adekuat, serta kesulitan dalam mengelola waktu. Selain mengidentifikasi permasalahan, artikel ini juga memuat dan menawarkan tips-tips praktis untuk mengatasi masalah-masalah akademik remaja.

\section{b. Memilih Jurusan dan Sekolah}

Tema ini ditulis tidak terlepas dari kebingungan dan kebimbangan remaja saat harus menentukan sekolah setelah mereka lulus SMP dan atau ketika mereka memilih jurusan di SMA/SMK. Dalam artikel ini dijelaskan kiat dan faktor-faktor yang sebaiknya dipertimbangkan oleh remaja pada saat mereka mengambil keputusan tentang pilihan jurusan dan sekolah.

\section{c. Remaja dan Orang Tua: Mari Berkomunikasi}

Masa remaja merupakan masa peralihan bagi individu (dari fase anak-anak ke fase dewasa) yang membutuhkan proses adaptasi yang adekuat agar fase transisi ini bisa dilewati dengan baik oleh individu tersebut. Salah satu aspek yang harus diantisipasi dan dibangun dalam fase remaja yaitu relasi dan komunikasi yang positif antara remaja dan orang tua. Komunikasi yang efektif dan positif antara orang tua dan remaja merupakan faktor yang bisa mendukung remaja dalam melewati fase-fase penuh gejolak ini. Artikel ini memuat tips baik bagi orang tua dan remaja dalam mengembangkan dan mempertahankan komumikasi yang efektif dan positif antara kedua belah pihak.

\section{d. Menjadi Aktif Menuju Sukses}

Mengeksplorasi skill, minat, bakat seluas dan sedalam mungkin merupakan salah satu tugas perkembangan remaja yang cukup krusial sebagai bekal untuk menapak dan mencapai kesuksesan di masa dewasa. Semakin awal remaja mengetahui dan memperkuat minat dan bakatnya, maka semakin lebih mudah jalan yang ia tempuh dalam menapaki fase dewasa. Dalam artikel ini akan dijelaskan kiat-kiat bagi remaja agar dapat aktif mengikuti berbagai aktivitas untuk mengeksplorasi dan mengembangkan bakat dan minatnya.

\section{e. Merajut Karir Sejak Dini}

Menentukan cita-cita dan marajut karir untuk masa depan pada dasarnya bisa dilakukan semenjak masa remaja. Lebih awal individu mengidentifikasi pilihan karir/pekerjaan, semakin mudah dan fokus bagi individu tersebut untuk mempersiapkan dan mengembangkan kemampuan diri. Artikel ini membahas aspek- 
aspek yang bisa membantu remaja dalam memilih dan menentukan pilihan karir untuk masa depan.

\section{f. Cara Mudah dan Ramah Bermedia Sosial}

Penggunaan media sosial yang semakin meluas tidak dapat dilepaskan dari kemajuan teknologi dan informasi pada masa kini. Hampir semua kalangan dan usia dapat mengakses dan menggunakan media sosial, tidak terkecuali kelompok remaja. Media sosial bila digunakan secara tepat dan bijak akan memberikan manfaat dan keuntungan bagi penggunanya. Sebaliknya bila media sosial disalahgunakan akan merugikan berbagai pihak termasuk diri sendiri. Artikel ini menawarkan tips-tips menggunakan media sosial yang positif sehingga remaja dapat memperoleh manfaat dan nilai tambah dari aktivitasnya di media sosial.

\section{Pembuatan Poster}

Poster didesain dan dicetak setelah artikel psikoedukasi selesai dibuat (contoh semua poster terdapat di bagian lampiran). Materi dan content dari poster pada dasarnya mengadopsi isi dari artikel meskipun terdapat beberapa modifikasi judul dan kalimat agar lebih singkat dan menarik serta sesuai dengan format poster. Jumlah poster yang dicetak sebanyak 6 buah, berukuran A3 dan dicetak dalam bentuk full color. Poster sudah diserahkan kepada RPTRA Anggrek dan sudah terpasang di papan informasi. Selain dalam format cetak, tim pelaksana dari UPJ juga menyerahkan materi dalam bentuk e-poster dengan harapan staf RPTRA dapat mensosialisasikan ke publik yang lebih luas. Selain itu, e-poster juga akan disebarkan melalui media sosial antara lain Whatsapp Group, Instagram, Facebook dan lain sebagainya. Tabel 2 menjelaskan topiktopik poster yang dicetak dan ditampilkan di papan informasi RPTRA Anggrek sedangkan gambar 5 menunjukkan contoh poster yang telah dicetak dan disebarluaskan.

Tabel 2. Topik poster

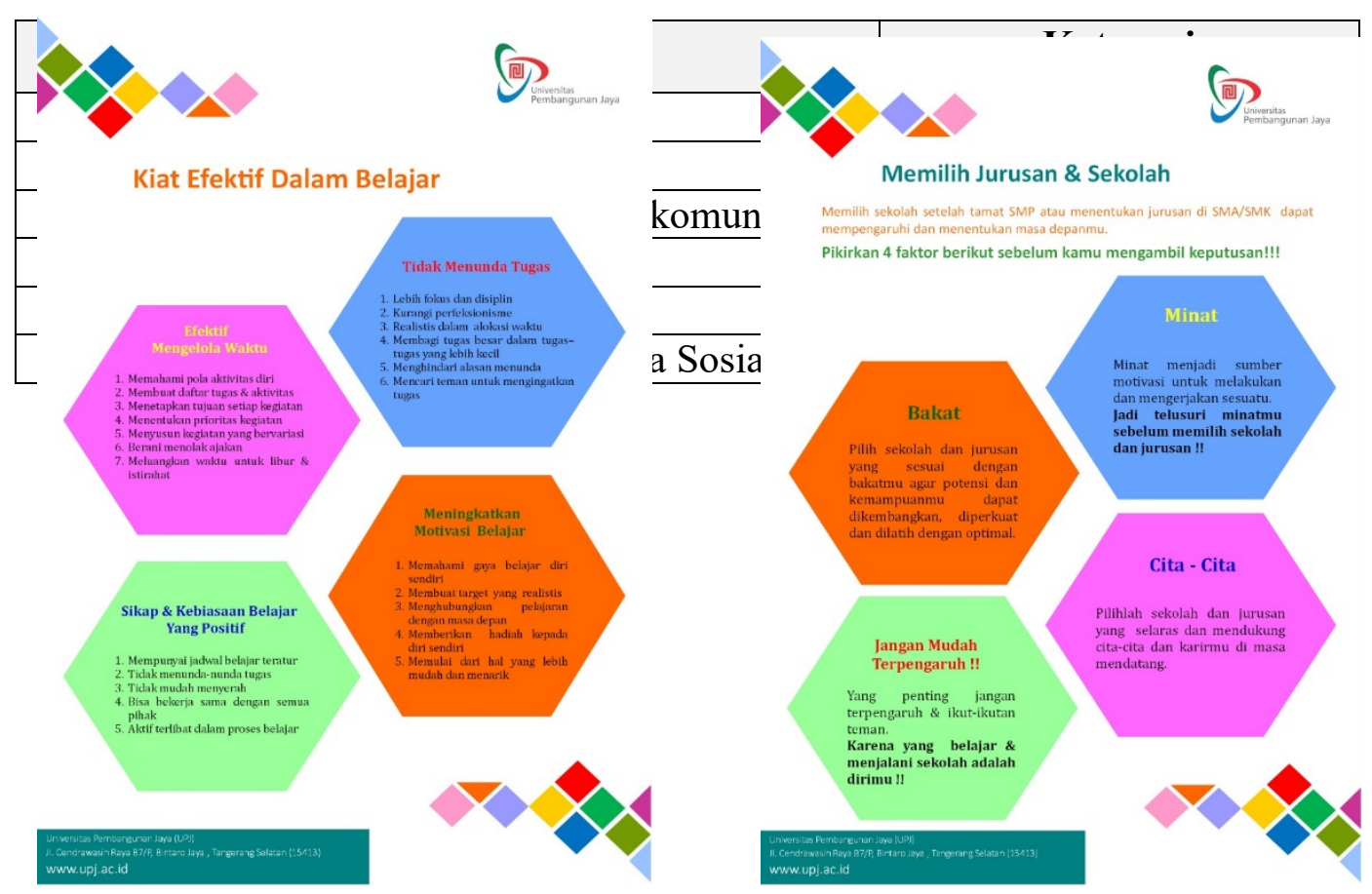


Gambar 5. Contoh Poster Psikoedukasi Remaja

\section{Artikel Ilmiah}

Artikel ilmiah yang menjelaskan tujuan, proses, hasil dan pencapaian, serta kesimpulan dan saran dari kegiatan Pengabdian Masyarakat di RPTRA Anggrek telah disusun oleh tim pelaksana (materi artikel ilmiah terdapat di bagian lampiran). Abstrak dari artikel juga sudah disubmit dan diterima untuk dipresentasikan pada seminar nasional yang akan dilaksanakan di kota Pekanbaru, Provinsi Riau. Dengan mengikuti event seminar tersebut, harapannya artikel ini dapat diterbitkan dalam jurnal atau proceeding.

\section{Konferensi/Seminar Nasional}

Hasil dari kegiatan Pengabdian Masyarakat di RPTRA akan dipresentasikan di Seminar Nasional yang bertajuk "Integrasi IPTEKes Dalam Penelitian dan Pengabdian Untuk Peradaban Bangsa" yang diselenggarakan pada tanggal 16 Desember 2017 di kota Pekanbaru, Provinsi Riau.

\section{Buku}

Sampai masa pelaksanaan Pengabdian Masyarakat ini berakhir, buku yang memuat artikel psikoedukasi belum diterbitkan karena masih menunggu periode penerbitan buku dari KPIN. Selama menunggu periode penerbitan buku tersebut, tim pelaksana mempersiapkan format artikel agar sesuai dengan ketentuan yang ditetapkan oleh KPIN.

\section{KESIMPULAN DAN SARAN}

Kegiatan Pengabdian Masyarakat yang bertajuk "Pusat Informasi Kecakapan Hidup (Life Skills) Untuk Remaja Dan Keluarga Urban" ini telah dilaksanakan dengan melibatkan tim dari program studi Psikologi, program studi Manajemen UPJ dan staf RPTRA Anggrek, Bintaro. Selama kurang lebih enam (6) bulan waktu pelaksanaan kegiatan, tim gabungan ini telah bekerja dengan baik dan mampu memberikan kontribusi yang maksimal sesuai dengan perannya masing-masing. Output yang berhasil dicapai selama berlangsungnya kegiatan antara lain: pembuatan papan informasi, pembuatan artikel psikoedukasi dengan tema life skills (personal skills, social skills, vocational skills dan academic skills), pencetakan dan penyebaran poster, penulisan artikel ilmiah, penulisan artikel untuk buku, pemuatan artikel di jurnal/proceeding serta keikutsertaan di seminar nasional.

Salah satu yang belum dilaksanakan pada kegiatan enam bulan ini yaitu mengukur tingkat pengetahuan dan pemahaman kelompok target tentang life skills. Hal ini dikarenakan untuk 
mengukur perubahan pengetahuan diperlukan waktu kurang lebih antara 1-3 bulan secara periodik setelah program intervensi dilakukan. Oleh karena itu tim pelaksana menyarankan agar dalam rentang waktu 1 sampai 3 bulan setelah program ini berakhir, dilaksanakan evaluasi untuk mengetahui efektivitas dari pelaksanaan program. Tim pelaksana juga menyarankan agar di masa mendatang kegiatan pemberian informasi dengan topik-topik yang lebih beragam dapat terus dilaksanakan, baik oleh program studi Psikologi dan Manajemen, maupun oleh program studi lain yang ada di UPJ. Selain untuk menambah pengetahuan dan wawasan, hal ini juga dapat bermanfaat demi keberlanjutan program dan untuk memperkuat fungsi RPTRA Anggrek, Bintaro sebagai pusat layanan dan informasi bagi masyarakat sekitar.

\section{UCAPAN TERIMAKASIH}

Program Pengabdian Masyarakat ini merupakan salah satu bentuk sumbangsih Program Studi Psikologi dan Manajemen Universitas Pembangunan Jaya (UPJ) dalam usaha berkontribusi dan meningkatkan kesejahteraan masyarakat urban. Dalam proses pelaksanaannya terdapat beberapa pihak yang ikut mendukung dan terlibat dalam program ini. Oleh karena itu tim pelaksana mengucapkan terima kasih kepada Unit Penelitian dan Pengabdian Masyarakat (P2M) Universitas Pembangunan Jaya dan semua staf RPTRA Anggrek Bintaro.

\section{DAFTAR PUSTAKA}

Supriatna, M.dkk. (2005). Konsep Pendidikan Berorientasi Kecakapan Hidup di Sekolah Menengah Pertama. Jakarta: Depdiknas.

Amirin, T.M. (2002). Landasan filosofis pendidikan berwawasan kecakapan hidup (Life skills). Dinamika Pendidikan No. 1/Tahun IX/Maret 2002.

Lembaga Penelitian dan Pengabdian Masyarakat Universitas Pembangunan Jaya (2016) Rencana induk pengabdian kepada masyarakat 2016-2026 urban development and urban lifestyle Bintaro Jaya: Universitas Pembangunan Jaya.

Supriyanto, Soerjoatmodjo, G.W.L. \& Prasetio, T. (2017). Gambaran pengasuhan anak pada keluarga urban yang tinggal di wilayah RPTRA Anggrek Bintaro, Jakarta Selatan. Jurnal Muara, Ilmu Sosial, Humaniora dan Seni, Vol. 1 No. 1: 30-41.

Universitas Pembangunan Jaya (2016d) Perjanjian kerjasama antara Pemerintah Provinsi

Daerah Khusus Ibukota Jakarta dengan Universitas Pembangunan Jaya tentang Pembinaan dan Pendampngan Program Kependudukan Keluarga Berencana dan Pembangunan Keluarga No. 008/PER-REK/UPJ/06.16 Bintaro Jaya: Universitas Pembangunan Jaya.

Universitas Pembangunan Jaya (2017). Kurikulum KOTA Universitas Pembangunan Jaya. Unit KOTA Universitas Pembangunan Jaya.

Antara. (2016). Pemprov DKI resmikan RPTRA Anggrek Bintaro.Diakses dari

http://www.antaranews.com/berita/541029/pemprov-dki-resmikan-rptra-anggrekbintaro pada tanggal 28 Desember 2016.

Detik (2015) Mengenal Lebih Jauh RPTRA, Taman Multifungsi di Sudut-Sudut Ibu Kota.

Diakses dari https://news.detik.com/berita/2951941/mengenal-lebih-jauh-rptra-tamanmultifungsi-di-sudut-sudut-ibu-kota pada tanggal 28 Desember 2016.

Departmen Pendidikan Nasional Pusat Pengembangan Kualitas Jasmani. (2007). Pendidikan 
kecakapan hidup untuk pencegahan HIV dan AIDS Jakarta: Pusat Pengembangan Kualitas Jasmani Departmen Pendidikan Nasional.

Kompasiana (2016) Ruang Publik Terpadu Ramah Anak (RPTRA). Diakses dari

http://www.kompasiana.com/musarustam/ruang-publik-terpadu-ramah-anakrptra 560bae4c167b6105084fb3f6 pada tanggal 28 Desember 2016.

Konsorsium Psikologi Ilmiah Nusantara (2016). Seputar konsorsium. Diakses dari http://k-pin.org/seputar-konsorsium/ pada tanggal 28 Desember 2016.

Universitas Pembangunan Jaya (2016a). Jaya Softskills Development Program. Diakses dari http://www.upj.ac.id/pages/33/jsdp.html pada tanggal 28 Desember 2016.

Universitas Pembangunan Jaya (2016b). Kelas Open To All. Diakses dari http://www.upj.ac.id/pages/32/open-to-all.html pada tanggal 28 Desember 2016.

Universitas Pembangunan Jaya (2016c) Keterlibatan tim UPJ dalam pembangunan RPTRA Villa Anggrek. Diakses dari http://upj.ac.id/news/144/keterlibatan-tim-upj-dalampem.html pada tanggal 28 Desember 2016. 